\title{
The Identification and Synthesis of Lead Apatite Minerals Formed in Lead Water Pipes
}

\author{
Jeremy D. Hopwood, ${ }^{1}$ Glyn R. Derrick, ${ }^{1}$ David R. Brown, ${ }^{1}$ Christopher D. Newman, \\ John Haley, ${ }^{2}$ Richard Kershaw, ${ }^{2}$ and Mike Collinge ${ }^{2}$ \\ ${ }^{1}$ Department of Chemistry, University of Huddersfield, Huddersfield, West Yorkshire HD13DH, UK \\ ${ }^{2}$ Yorkshire Water, Yorkshire Water Services, Western House, Western Way, Halifax Road, P.O. Box 500, Bradford, \\ West Yorkshire BD6 2SZ, UK
}

Correspondence should be addressed to Jeremy D. Hopwood; jeremy.hopwood@hud.ac.uk

Received 10 December 2015; Accepted 31 January 2016

Academic Editor: Jean-Marie Nedelec

Copyright (C) 2016 Jeremy D. Hopwood et al. This is an open access article distributed under the Creative Commons Attribution License, which permits unrestricted use, distribution, and reproduction in any medium, provided the original work is properly cited.

\begin{abstract}
Phosphate is added to drinking water in the UK to minimise the release of lead from lead water pipes. The phosphate encourages the formation of insoluble lead apatites on the walls of the pipe. Hydroxylpyromorphite $\mathrm{Pb}_{5}\left(\mathrm{PO}_{4}\right)_{3} \mathrm{OH}$ is the lead apatite that is most often used to model lead levels in tap water; however, its presence has not been confirmed. Our aims were to identify the lead pipe apatite and synthesise it. The synthetic mineral would then be used in future solubility studies to produce better predictions of lead levels in tap water. XRD and FTIR were used to characterise the minerals on a range of lead pipes. Pyromorphite and hydroxylpyromorphite were absent and instead a range of mixed calcium lead apatites were present. For every five lead ions in the general formula $\mathrm{Pb}_{5}\left(\mathrm{PO}_{4}\right)_{3} \mathrm{X}$ between one and two ions were replaced with calcium and there was evidence of substitution of $\mathrm{PO}_{4}{ }^{3-}$ by either $\mathrm{CO}_{3}{ }^{2-}$ or $\mathrm{HPO}_{4}{ }^{2-}$. Calcium lead apatites with similar unit cell dimensions to those found on lead water pipes were then synthesised. The calcium: lead ratio in these reaction mixtures was in excess of $500: 1$ and the resulting crystals were shown by TEM to be nanosized rods and flakes. The synthetic apatites that most closely resembled the unit cell dimensions of the apatites on lead water pipes were shown to be $\mathrm{Pb}_{3.4} \mathrm{Ca}_{1.3}\left(\mathrm{PO}_{4}\right)_{3} \mathrm{Cl}_{0.03} \mathrm{OH}_{0.97}, \mathrm{~Pb}_{3.6} \mathrm{Ca}_{1.2}\left(\mathrm{PO}_{4}\right)_{3} \mathrm{Cl}_{0.07} \mathrm{OH}_{0.93}$, and $\mathrm{Pb}_{3.6} \mathrm{Ca}_{1.2}\left(\mathrm{PO}_{4}\right)_{3} \mathrm{Cl}_{0.27} \mathrm{OH}_{0.73}$.
\end{abstract}

\section{Introduction}

Lead is a harmful heavy metal that is associated with poor cognitive performance at low levels of exposure $[1,2]$ and organ failure at high levels of exposure $[3,4]$. Environmental lead levels have fallen in the UK over the last 30 years due to the discontinuation of lead in petrol and paints [5], although a historical legacy remains [6]. Many homes built before 1970 are connected to the mains water pipe in the street by a lead pipe [1, 7-9]. Although lead pipe replacement is the best option it is costly and therefore rarely undertaken by the homeowner. Recently the issue of lead in tap water has been highlighted by events taking place in Flint, Michigan, USA, where high levels of lead have been recorded [10].

Research by Colling in the 1980s showed that low levels of phosphate $(1-3 \mathrm{mg} / \mathrm{L}$ as $\mathrm{P})$ added to tap water can reduce the concentration of soluble lead [11, 12]. This practice has been adopted by water utilities worldwide and in the UK has enabled water utilities to compliant with lead levels [9]. Recently the focus of UK water utilities has been on complying with the new European Union 2013 legal limit of $10 \mu \mathrm{g} / \mathrm{L}$. For some, this has meant identifying supply zones that do not respond as well to phosphate dosing. These socalled "lead hot spots" are $<98 \%$ compliant with the $10 \mu \mathrm{g} / \mathrm{L}$ limit. Understanding why these occur has led to renewed interest in optimising phosphate dosing procedures and in understanding the chemistry of lead water pipes.

The corrosion of lead pipes results in the formation of a thin mineralised corrosion layer [11, 13-17]. This layer typically contains lead oxide (litharge) overlaid with lead carbonates (cerussite and hydrocerussite). In the case of phosphate dosing a further layer containing lead apatite is thought to occur. In phosphate-dosed tap water, the lead apatites are the least soluble form of lead [18] and it is thought 
that these are the minerals that control the concentration of dissolved lead in tap water.

Lead apatite is the name used in this paper to describe minerals of general formula $\mathrm{M}_{5}\left(\mathrm{PO}_{4}\right)_{3} \mathrm{X}$, where $\mathrm{M}$ is either $\mathrm{Pb}^{2+}$ or a mixture of $\mathrm{Pb}^{2+}$ and one other cation such as $\mathrm{Ca}^{2+}$ and $\mathrm{X}$ is a monovalent anion such as $\mathrm{OH}^{-}$or $\mathrm{Cl}^{-}$. Examples include pyromorphite $\mathrm{Pb}_{5}\left(\mathrm{PO}_{4}\right)_{3} \mathrm{Cl}$, hydroxylpyromorphite $\mathrm{Pb}_{5}\left(\mathrm{PO}_{4}\right)_{3} \mathrm{OH}$, and phosphohedyphane $\mathrm{Pb}_{3} \mathrm{Ca}_{2}\left(\mathrm{PO}_{4}\right)_{3} \mathrm{Cl}$. Lead apatites are closely related in formula and crystal structure to calcium apatites [19], which have been extensively studied because they form the mineral component of bones and teeth. Examples of the calcium apatites include hydroxylapatite $\mathrm{Ca}_{5}\left(\mathrm{PO}_{4}\right)_{3} \mathrm{OH}$, chlorapatite $\mathrm{Ca}_{5}\left(\mathrm{PO}_{4}\right)_{3} \mathrm{Cl}$, and fluoroapatite $\mathrm{Ca}_{5}\left(\mathrm{PO}_{4}\right)_{3} \mathrm{~F}$.

There is uncertainty about the chemical formulae of the lead apatites found on lead water pipes. Hydroxylpyromorphite $\left(\mathrm{Pb}_{5}\left(\mathrm{PO}_{4}\right)_{3} \mathrm{OH}\right)$ is the phase that is most often used in solubility studies [20]. However, Grimes et al. identified a calcium containing lead apatite on new lead pipes exposed to phosphate-dosed tap water and analysis by electron diffraction implied that the structure of the mineral was between hydroxylapatite $\left(\mathrm{Ca}_{5}\left(\mathrm{PO}_{4}\right)_{3} \mathrm{OH}\right)$ and hydroxylpyromorphite $\left(\mathrm{Pb}_{5}\left(\mathrm{PO}_{4}\right)_{3} \mathrm{OH}\right)$ [21]. Davidson et al. have also shown by secondary ion mass spectrometry that a correlation exists between calcium and phosphorus in the mineral scale and have interpreted this as evidence for a mixed calcium lead apatite $[15,22]$. Recently, a new geological lead apatite mineral called phosphohedyphane $\mathrm{Ca}_{2} \mathrm{~Pb}_{3}\left(\mathrm{PO}_{4}\right)_{3} \mathrm{Cl}$ has been identified and its crystallography determined [23].

The lead apatites belong to a large group of minerals having the apatite crystal structure (space group $\mathrm{Pb}_{3} / \mathrm{m}$ ). The different members are usually described in terms of their unit cell data obtained from X-ray diffraction. Figure 1 shows published unit cell data as a plot of the $c$ dimension versus the $a, b$ dimension for five minerals hydroxylapatite [24, 25], chlorapatite [26], phosphohedyphane [23], hydroxylpyromorphite [27, 28], and pyromorphite [29-32]. The graph shows that the calcium lead apatite unit cell dimensions exist within a quadrilateral. The fact that phosphohedyphane, $\mathrm{Pb}_{3} \mathrm{Ca}_{2}\left(\mathrm{PO}_{4}\right)_{3} \mathrm{Cl}$, is $3 / 5$ of the way along the line from $\mathrm{Ca}_{5}\left(\mathrm{PO}_{4}\right)_{3} \mathrm{Cl}$ to $\mathrm{Pb}_{5}\left(\mathrm{PO}_{4}\right)_{3} \mathrm{Cl}$ is consistent with a linear dependence of the unit cell dimensions on the ratio of $\mathrm{Pb}: \mathrm{Ca}$.

Identifying the lead apatites present on the lead water pipes and knowing their solubility products would enable much better predictions to be made of lead levels in tap water of different water quality. Unfortunately, it is difficult to do this directly on the in situ lead apatites. This is because the mineral corrosion layer is a mixture of cerussite, hydrocerussite, and lead apatite. It would be difficult to physically separate the lead apatites for solubility studies without contaminating the mineral with cerussite or hydrocerussite or chemically separate them without altering the surface structure of the apatites. Similar problems have beset those trying to understand the solubility of bones and teeth as these are mixtures of different calcium apatites [33]. In the case of bones and teeth synthetic calcium apatites have been prepared and these have then been used in solubility studies [34]. A similar strategy of identifying and making synthetic copies of the lead apatites is used in this study. The long term

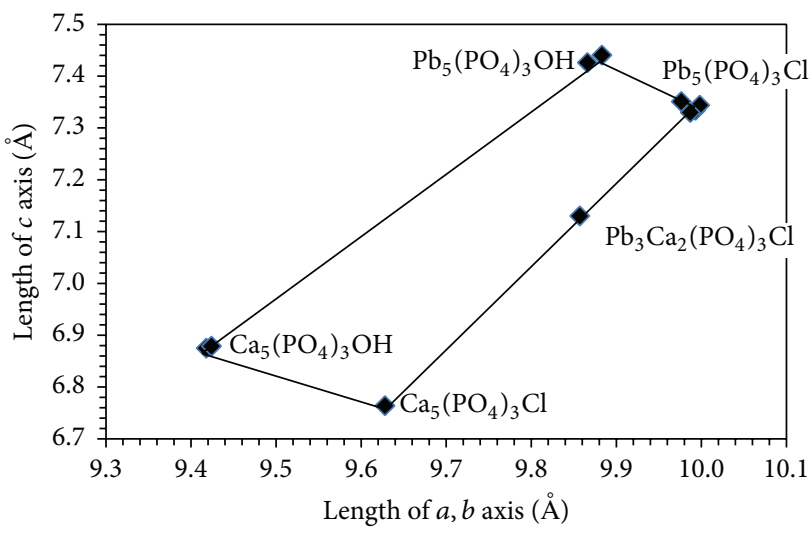

FIGURE 1: Unit cell graph for apatites containing calcium, lead, hydroxide, and chloride ions (see text for references).

aim is to produce better predictions of lead levels in tap water, which can be used to optimise phosphate dosing and to shed light on the occurrence of "lead hot spots." The ability to make synthetic copies of the lead apatites found on the walls of lead water pipes is a crucial first step.

The results presented here will also be of interest to those studying the immobilisation of lead in contaminated soil [3538] and the immobilisation of lead in the ash produced from municipal solid waste incineration (MSWI) plants [39-41]. In both cases, phosphate has been used to produce lead apatites, the low solubility of which reduces the bioavailability of lead. Calcium is likely to be a coprecipitant in these apatites.

In this study, powder XRD was used to identify the minerals present in the lead pipe corrosion layer and to show which peaks corresponded to lead apatite. FTIR was used to support the XRD work and to show whether or not foreign anions such as carbonate were incorporated in the apatite structure. Synthetic calcium lead apatites were then prepared from solutions containing different ratios of $\mathrm{Ca}: \mathrm{Pb}$ and $\mathrm{OH}: \mathrm{Cl}$ and samples analysed by powder XRD and FTIR. Transmission electron microscopy (TEM) was used to determine the size and morphology of the synthetic lead apatites. The unit cell dimensions of the apatites formed on the lead pipes and the synthetic apatites were then calculated and their positions on the unit cell graph compared. Finally, three target minerals (T1, T2, and T3) were prepared whose unit cell dimensions were similar to the apatites formed on the lead pipes. The chemical formulae of these target minerals, the synthetic copies of the lead apatites found on the walls of lead water pipes, were then determined chemically by elemental analysis.

\section{Materials and Methods}

2.1. Extraction of Lead Pipes and Preparation of Mineral Scale. Lead communication pipes were extracted by Yorkshire Water. They were taken from properties within Yorkshire, $\mathrm{UK}$, in 2010 and were thought to be between 60 and 80 years old.

Eight pipes (P2, P4, P5, P8, P11, P12, P13, and P14) came from compliance zones with moderate alkalinity, $100 \pm$ $20 \mathrm{mg} / \mathrm{L} \mathrm{CaCO}_{3}$, and an average $\mathrm{pH}$ of 7.2. Four pipes (P1, P3, 
TABLE 1: Composition of solutions 1 and 2 used to make the synthetic calcium lead apatites, S1-S10 and T1-T3.

\begin{tabular}{lccccccccc}
\hline & Code & \multicolumn{3}{c}{ Solution 1, 100 mL } & \multicolumn{3}{c}{ Solution 2, $1000 \mathrm{~mL}$} & & Mix \\
& & $\begin{array}{c}\mathrm{Na} \mathrm{HPO}_{4} \\
(\mathrm{mM})\end{array}$ & $\begin{array}{c}\mathrm{NaCl} \\
(\mathrm{mM})\end{array}$ & $\mathrm{pH}$ & $\begin{array}{c}\mathrm{Ca}\left(\mathrm{NO}_{3}\right)_{2} \\
(\mathrm{mM})\end{array}$ & $\begin{array}{c}\mathrm{Pb}\left(\mathrm{NO}_{3}\right)_{2} \\
(\mathrm{mM})\end{array}$ & $\mathrm{Ca} / \mathrm{Pb}$ & $\mathrm{pH}$ & $\mathrm{pH}$ \\
\hline \multirow{3}{*}{ Chloride } & $\mathrm{S} 1$ & 10 & 250 & 8.44 & 250 & 0.5 & 500 & 5.37 & 5.69 \\
experiments & $\mathrm{S} 2$ & 10 & 25 & - & 250 & 0.5 & 500 & 5.37 & - \\
& $\mathrm{S} 3$ & 10 & 2.5 & 9.22 & 250 & 0.5 & 500 & 5.37 & - \\
& $\mathrm{S} 4$ & 10 & 0.25 & 9.14 & 250 & 0.5 & 500 & 5.37 & - \\
\hline \multirow{4}{*}{ Calcium } & $\mathrm{S} 5$ & 10 & 0.025 & 9.2 & zero & 0.5 & 0 & 5.43 & 7.16 \\
experiments & $\mathrm{S} 6$ & 10 & 0.025 & 9.2 & 250 & 0.5 & 500 & 5.37 & - \\
& $\mathrm{S} 7$ & 10 & 0.025 & 9.2 & 500 & 0.5 & 1000 & 5.37 & - \\
& $\mathrm{S} 8$ & 10 & 0.025 & 9.2 & 750 & 0.5 & 1500 & 5.30 & - \\
& $\mathrm{S} 9$ & 10 & 0.025 & 9.2 & 1000 & 0.5 & 2000 & 5.23 & - \\
\hline \multirow{2}{*}{ Target } & $\mathrm{S} 10$ & 10 & 0.025 & 9.2 & 1250 & 0.5 & 2500 & 5.20 & - \\
minerals & $\mathrm{T} 1$ & 10 & 0.025 & 9.2 & 940 & 0.5 & 1880 & - & - \\
& $\mathrm{T} 2$ & 10 & 0.025 & 9.2 & 690 & 0.5 & 1380 & 5.18 & 4.98 \\
& $\mathrm{~T} 3$ & 10 & 0.50 & 9.1 & 660 & 0.5 & 1320 & 5.23 & 5.26 \\
\hline
\end{tabular}

$\mathrm{P} 7$, and P9) came from compliance zones with high alkalinity $\left(250 \pm 50 \mathrm{mg} / \mathrm{L} \mathrm{CaCO}_{3}\right)$ and average $\mathrm{pH}$ range of 7.2-7.6. Two pipes (P6 and P10) were not supplied with water quality data. The pipes, P1 to P14 (internal diameter 10-15 mm), were drained on-site and their ends covered in plastic bags before being sent to the laboratory. They were then dried at room temperature, cut into 5-7 cm long lengths using a ratchet PVC and HDPE pipe cutter, and stored at room temperature. Samples of mineral scale from pipes P1 to P14 were removed in a beaker of tap water by scraping the internal surface of the lead pipes with a stainless steel spatula. The resulting solution was then centrifuged and the powder collected and dried overnight at $80^{\circ} \mathrm{C}$.

2.2. Synthesis of Lead Apatites. Calcium nitrate tetrahydrate, sodium phosphate dibasic dihydrate, sodium chloride, and lead(II) nitrate were obtained from Sigma Aldrich. Ultrapure water was produced using a Thermo Scientific Nanopure Ultrapure Water System.

Initial work established that a $\mathrm{Ca}: \mathrm{Pb}$ ratio of the order $500: 1$ was needed to make the calcium lead apatites. The synthetic minerals, S1-S10, were produced by mixing a phosphate-chloride solution (solution 1) with a lead-calcium solution (solution 2). All the solutions were bubbled with nitrogen gas to remove dissolved $\mathrm{CO}_{2}$ gas. This was undertaken because carbonate ions are known to substitute for up to $3.6 \%$ of the phosphate ions in lead apatites [42]. The phosphate-chloride solution $(\mathrm{pH} 8.4-9.2)$ was made by mixing dibasic sodium phosphate $(0.100 \mathrm{M}, 10.0 \mathrm{~mL})$ with sodium chloride $\left(1.67 \mathrm{M}-1.67 \times 10^{-4} \mathrm{M}, 15 \mathrm{~mL}\right)$ and made up to $100 \mathrm{~mL}$ with ultrahigh purity water. The lead-calcium solution ( $\mathrm{pH}$ 5.2-5.4) was made by mixing lead(II) nitrate $(0.040 \mathrm{M}, 12.5 \mathrm{~mL})$ with solid calcium nitrate tetrahydrate $(0.00-295 \mathrm{~g})$ and made up to $1000 \mathrm{~mL}$ with ultrahigh purity water. Solution $1(100 \mathrm{~mL})$ was added dropwise, over a period of 10 minutes, to solution $2(1000 \mathrm{~mL})$. The resulting cloudy white suspension was centrifuged (Eppendorf 5702,
$2500 \mathrm{rpm}, 2.5 \mathrm{mins}$ ) and washed five times with ultrapure water to remove any remaining calcium nitrate. The remaining solid was then filtered and dried overnight at $80^{\circ} \mathrm{C}$. Samples S1, S2, S3, S4, and S6 were used to investigate the effect of increasing the chloride concentration. Samples S5S10 were used to investigate the effect of increasing the calcium concentration. The solution compositions are shown in Table 1.

The target minerals $\mathrm{T} 1, \mathrm{~T} 2$, and $\mathrm{T} 3$ were prepared in the same manner as minerals S1-S10. The solution compositions were those that gave synthetic minerals whose unit cell dimensions were similar to those of the lead pipe apatites. Each target mineral was prepared three times and elemental analysis was undertaken on all nine samples.

It should be noted that the synthetic minerals S1-S10 and T1-T3 were made at a much higher supersaturation than those of the lead apatites found on the water pipes. The higher supersaturations were necessary in order to produce sufficient material for sample analysis and for future solubility experiments. The concentrations of lead and phosphate (as $\mathrm{P}$ ) in the synthetic experiments were $28 \mathrm{mg} / \mathrm{L}$ and $93000 \mu \mathrm{g} / \mathrm{L}$, respectively, whereas the concentration of lead and phosphate (as $\mathrm{P}$ ) in the lead water pipes would have been $1-3 \mathrm{mg} / \mathrm{L}$ and $2-20 \mu \mathrm{g} / \mathrm{L}$, respectively.

2.3. Analytical Methods. X-ray powder diffraction was carried out using a Bruker D2 PHASER fitted with a LYNXEYE ${ }^{\mathrm{m}}$ detector and $\mathrm{CuK} \alpha$ radiation $(\lambda=1.5418 \AA)$. Samples for XRD were ground to a fine powder and loaded into the centre of a mirror sample holder using ethanol. Peak positions were identified using XFIT 2 and the patterns refined using Chekcell [43]. The diffracted peaks of minerals other than those from lead apatite were removed prior to calculating the unit cell parameters. The initial values used as a starting point for the assignment were the unit cell parameters of hydroxylpyromorphite. FTIR spectra of the minerals were recorded on a Nicolet 380 spectrometer from 4000 to $400 \mathrm{~cm}^{-1}$ with a 
diamond ATR accessory. Transmission electron microscopy of synthetic minerals was undertaken using a JEOL 3010 TEM operated at $300 \mathrm{kV}$. The minerals for TEM analysis were dispersed in deionised water and a small drop was transferred to a Formvar-carbon coated copper grid and allowed to air dry. ICPMS data were recorded using an Agilent 7700e ICPMS. Yttrium and lead single element standards for ICP-MS were obtained from VWR. Elemental analysis of the three target minerals was carried out by an external contractor Medac Ltd. The minerals were digested in $5 \mathrm{~mL}$ conc. $\mathrm{HNO}_{3}$ and $1 \mathrm{~mL}(30 \% \mathrm{w} / \mathrm{v}) \mathrm{H}_{2} \mathrm{O}_{2}$ and made up to $100 \mathrm{~mL}$. The resulting solutions were then analysed for $\mathrm{Ca}, \mathrm{P}$, and $\mathrm{Pb}$ using a Varian Vista MPX ICP_OES. The $\mathrm{Cl}$ analysis was carried out by combustion of the sample in oxygen and absorption, followed by titration with mercuric nitrate solution.

\section{Results and Discussion}

3.1. The Lead Pipe Apatites. Peaks belonging to lead apatite were present in all the powder XRD patterns of the lead water pipes (Figure 2). Litharge $\mathrm{PbO}$, cerussite $\mathrm{PbCO}_{3}$, and hydrocerussite $\mathrm{Pb}_{3}\left(\mathrm{CO}_{3}\right)_{2}(\mathrm{OH})$ were also present as were a small number of peaks that could not be assigned. The predominance of these minerals varied from pipe to pipe as evidenced by the variation in the profile of the XRD patterns. The presence of cerussite and hydrocerussite is consistent with previous studies [14]. However, unlike previous studies, plattnerite $\mathrm{PbO}_{2}[13,44]$, scrutinyite $\mathrm{PbO}_{2}$ [44], laurionite $\mathrm{Pb}(\mathrm{OH}) \mathrm{Cl}$ [14], lead phosphate $\mathrm{Pb}_{9}\left(\mathrm{PO}_{4}\right)_{6}$ [14], and plumbonacrite $\mathrm{Pb}_{10}\left(\mathrm{CO}_{3}\right)_{6}(\mathrm{OH})_{6} \mathrm{O}$ [14] were not observed.

The positions of the lead apatite peaks varied slightly, which was consistent the presence of lead apatites of different formulae. Previous studies on hydroxylpyromorphite, pyromorphite, and phosphohedyphane have shown that there are eight X-ray diffraction peaks in the $2 \theta$ region $20^{\circ}-35^{\circ}$ that are associated with lead apatite minerals. These are the (200), (111), (002), (102), (210), (121), (112), and (300) peaks. Typically, the pipes P1-P14 showed between three and five of the eight peaks. The easiest peaks to identify were the (111) peaks at $21.5-22.5^{\circ} 2 \theta$ and the (121) and (112) peaks at 30.0$31.0^{\circ} 2 \theta$.

The unit cell dimensions of the apatites formed on lead pipes, as determined from powder XRD using XFIT and Chekcell, are shown in Figure 3. Each data point represents one sample. The errors due to curve fitting are shown by the error bars and were generated by Chekcell.

The apatites fall within a region of the quadrilateral bounded by the points $\mathrm{Pb}_{3} \mathrm{Ca}_{2}\left(\mathrm{PO}_{4}\right)_{3} \mathrm{OH}-\mathrm{Pb}_{3} \mathrm{Ca}_{2}\left(\mathrm{PO}_{4}\right)_{3} \mathrm{Cl}-$ $\mathrm{Pb}_{4} \mathrm{Ca}\left(\mathrm{PO}_{4}\right)_{3} \mathrm{Cl}-\mathrm{Pb}_{4} \mathrm{Ca}\left(\mathrm{PO}_{4}\right)_{3} \mathrm{OH}$. In this region, one to two of the lead atoms are substituted by calcium and both chloride and hydroxide are present.

Only one of the lead apatites had similar unit cell dimensions on the unit cell graph to phosphohedyphane. This was the apatite from pipe P4. However, most of the lead apatites were located away from the phosphohedyphane $\mathrm{Pb}_{3} \mathrm{Ca}_{2}\left(\mathrm{PO}_{4}\right)_{3} \mathrm{Cl}$ point on the quadrilateral. Five of the lead apatites (P1, P3, P5, P7, and P10) were close to the hydroxylphosphohedyphane $\mathrm{Pb}_{3} \mathrm{Ca}_{2}\left(\mathrm{PO}_{4}\right)_{3} \mathrm{OH}$ point on the

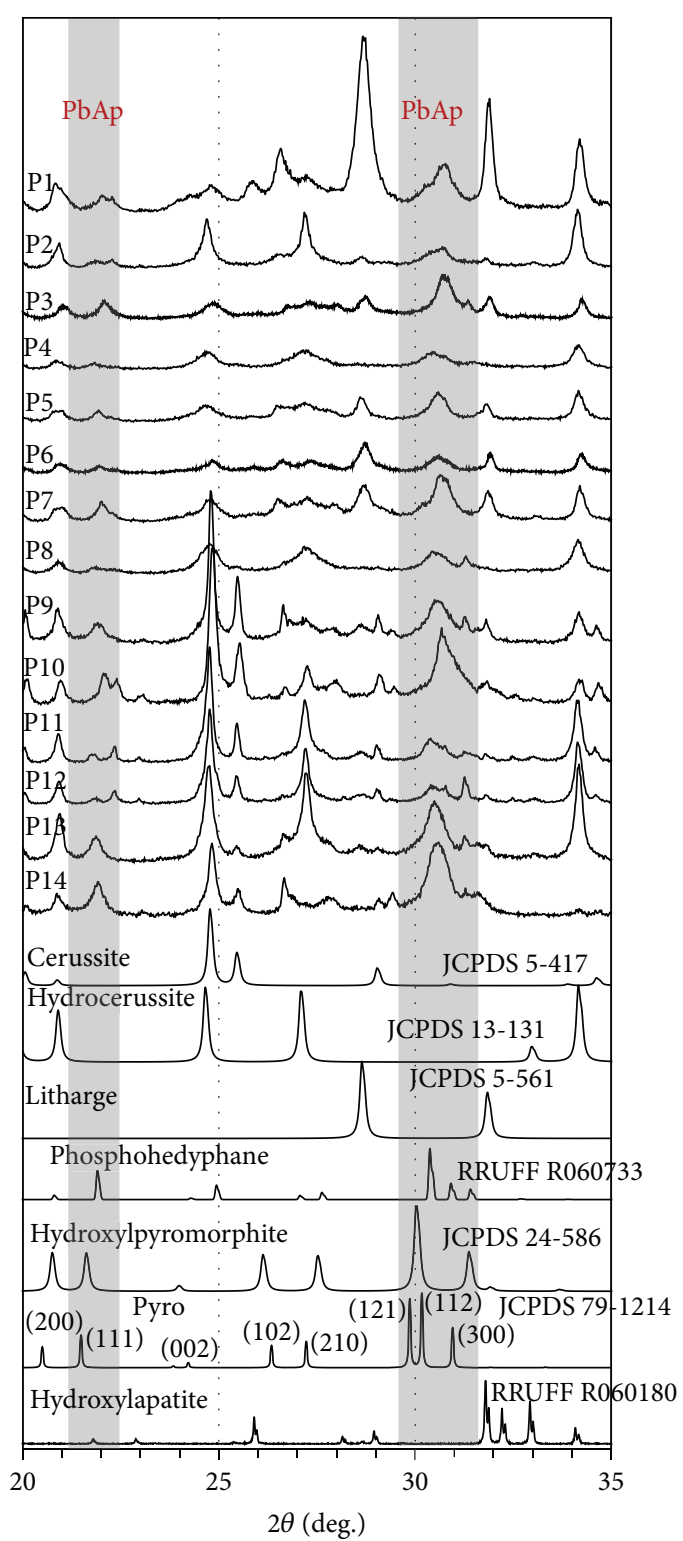

FIGURE 2: Lead mineral scale. X-ray powder diffraction patterns of lead pipes P1-P14 together with published reference spectra of oxide, carbonate, and phosphate minerals taken from the JCPDS and RRUFF databases. The prominent apatite peaks are shaded and the pattern for pyromorphite is indexed.

unit cell graph. None of the lead apatites were located near the hydroxylpyromorphite and pyromorphite points on the unit cell graph. Therefore, the data showed that the corrosion scale of the lead pipes contained more than one type of mixed calcium lead apatite and neither hydroxylpyromorphite nor pyromorphite was present.

The FTIR spectra of the corrosion scales of lead pipes P1P14 are shown in Figure 4.

Peaks for carbonate and phosphate were observed that were consistent with the presence of cerussite, hydrocerussite, and lead apatite. The precise identity, peak positions, and the modes of vibration were determined from published FTIR 


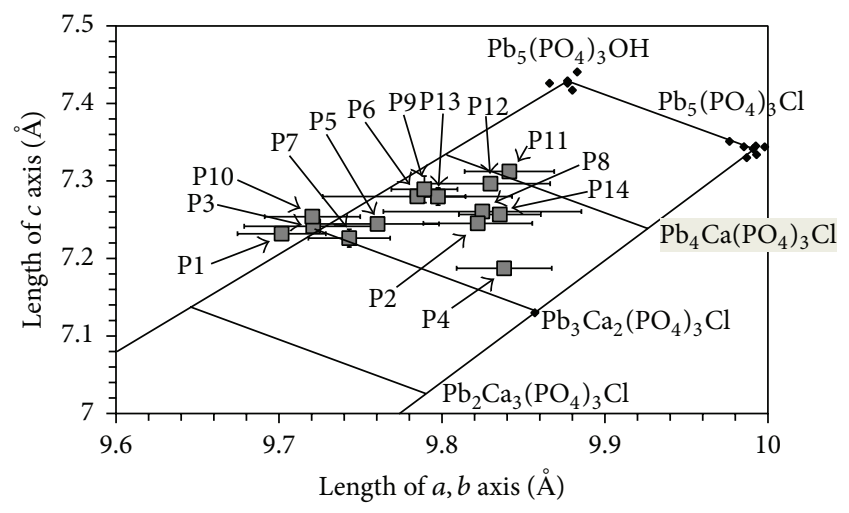

Figure 3: Unit cell graph for apatites from lead water pipes.

data on cerussite [17], hydrocerussite [17], hydroxylpyromorphite $[42,45]$, pyromorphite $[42,46-48]$ calcium lead apatite [45], and hydroxylapatite $[33,45,49,50]$. The broad peaks at 1300 to $1500 \mathrm{~cm}^{-1}$, the less intense but sharper peak at 670 $685 \mathrm{~cm}^{-1}$, and the small peak at $1045-1051 \mathrm{~cm}^{-1}$ are typical of the carbonate vibrations in either cerussite or hydrocerussite. The small peak at $839 \mathrm{~cm}^{-1}$ is characteristic of cerussite only. The intense peaks at $1000-1070 \mathrm{~cm}^{-1}$, the shoulder peak at $920 \mathrm{~cm}^{-1}$, and the medium sized peaks at $540 \mathrm{~cm}^{-1}$ and $570 \mathrm{~cm}^{-1}$ are typical of the $v_{3}, v_{1}$, and $v_{4}$ phosphate vibrations, respectively, in pyromorphite, hydroxylpyromorphite, and mixed calcium lead apatites.

Four of the lead pipes P9, P10, P12, and P14 had a peak at $870-880 \mathrm{~cm}^{-1}$ (marked $*$ in Figure 4). A peak at this position has been observed in spectra of hydroxylapatite and has been attributed either to the incorporation of carbonate into the hydroxylapatite structure, where carbonate occupies the phosphate position (type B substitution) [51] or to the substitution of phosphate ions for $\mathrm{HPO}_{4}{ }^{2-}$ ions $[33,50]$. Carbonate peaks at $850 \mathrm{~cm}^{-1}$ have also been reported in calcium lead apatites grown in the presence of sodium carbonate [42], although we have observed the peak at $870 \mathrm{~cm}^{-1}$ (unpublished work). Alternatively, a peak at this position could also be due small amounts of calcite.

3.2. The Synthetic Apatites. The powder XRD patterns of the synthetic apatites S1 to S10 are shown in Figure 5. All the patterns could be indexed for lead apatite and no other mineral was observed. Changes were observed in the degree of separation of the (121) and (112) peaks, which are the peaks most easily visible on patterns of the lead mineral scale. In sample S1, produced at high chloride concentration, the peaks were separate and appeared as a doublet, whereas in sample S4 produced at a low chloride concentration the peaks coincided and appeared as a singlet. A similar change from a doublet to a singlet can be seen in the diffraction patterns of pyromorphite and hydroxylpyromorphite. In other words, the doublet implies that the lead apatite is rich in chloride ions and the singlet implies that the lead apatite is rich in hydroxide ions. Varying the calcium concentration also affected the position of the (121) and (112) singlet peak. The peak shifted to higher $2 \theta$ values and smaller interplanar

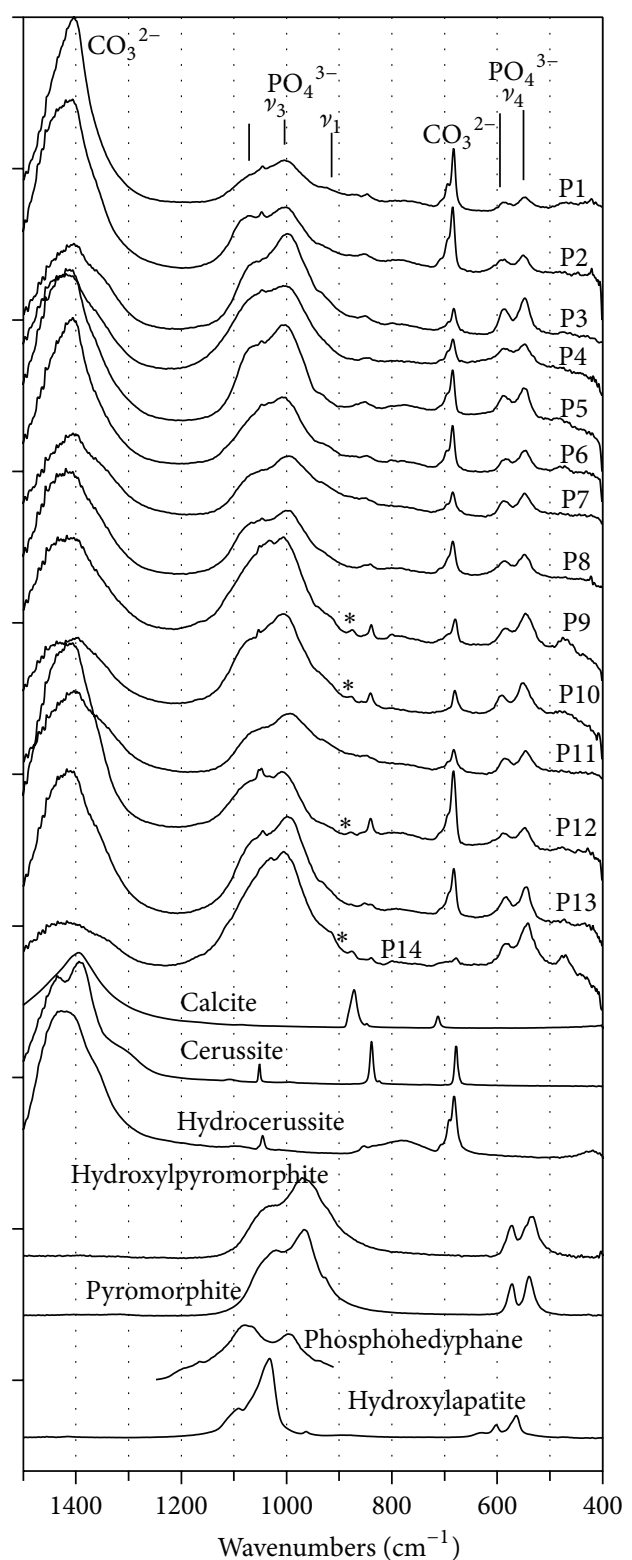

FIgUre 4: Lead mineral scale. Comparison of the FTIR spectra of lead pipes P1-P14 with spectra of carbonate and phosphate minerals. The spectra for phosphohedyphane was obtained from [23] and the other carbonate and phosphate standards were obtained from samples prepared in the laboratory.

$d$-spacings at higher calcium concentrations. This change is consistent with the incorporation of a smaller cation such as calcium into the crystal structure. XRD line broadening, which was a feature of the lead pipe apatites was also a feature for the synthetic apatites.

The positions of the synthetic lead apatites on the unit cell graph, as determined from powder XRD using XFIT and Chekcell, are shown in Figure 6. The error bars are smaller than those of the lead pipe apatites because only lead apatite was present, which made the curve fitting easier. The graph clearly shows that it is possible to move from the chloride side of the quadrilateral to the hydroxide side by decreasing 


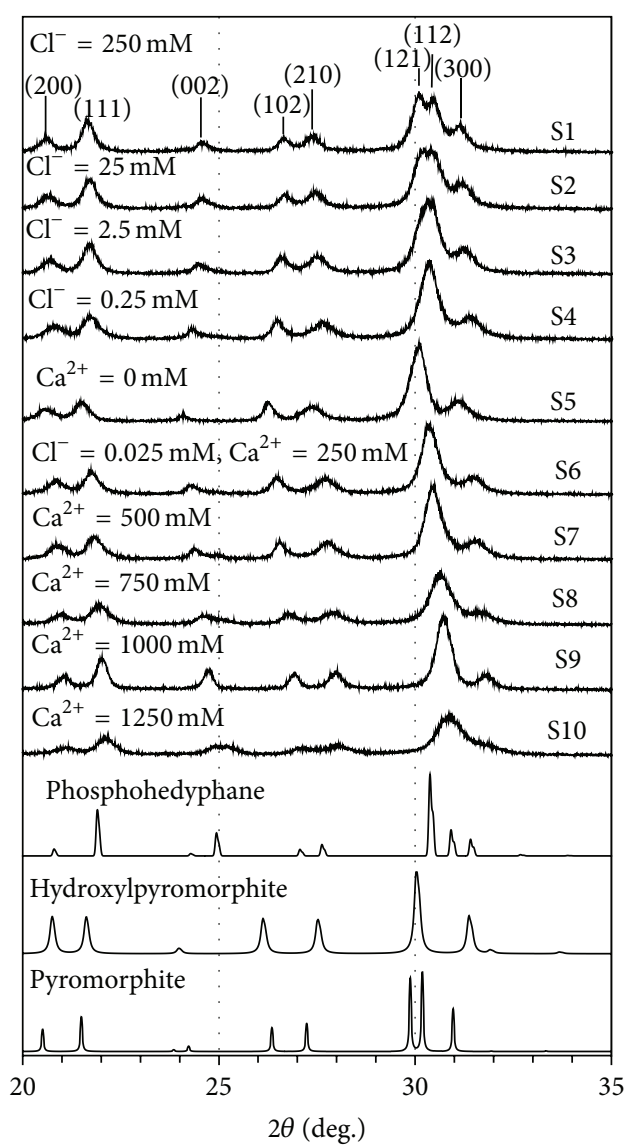

FIGURE 5: Synthetic apatites. X-ray powder diffraction patterns of synthetic calcium lead apatites S1-S10. The Miller indices are shown for sample S1.

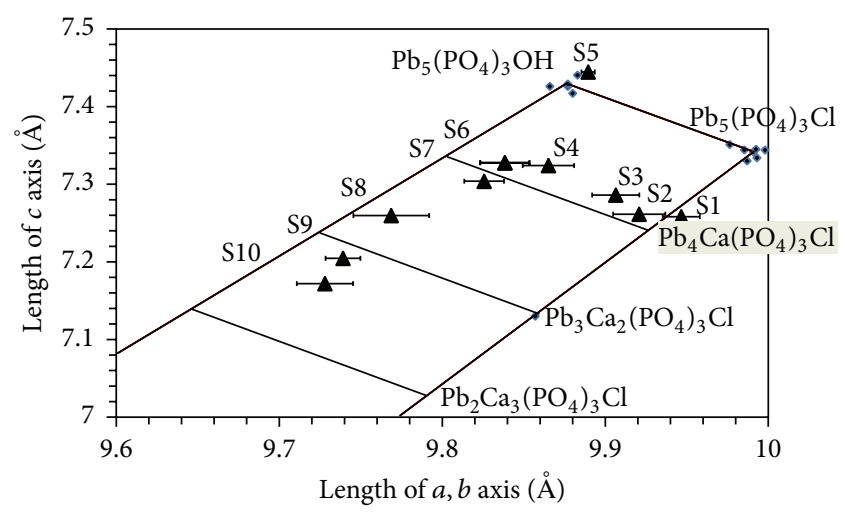

Figure 6: Unit cell graph for synthetic apatites S1-S10.

the concentration of chloride in the reaction mixture (S1S4, S6). Likewise, it is possible to move from the lead side of the quadrilateral to the calcium side by increasing the concentration of calcium in the reaction mixture (S5-S10). It is clear from the unit cell graph that a solid solution series exists for calcium lead apatite.

The FTIR spectra of samples S1-S10 are shown in Figure 7. The spectra were consistent with the presence of lead

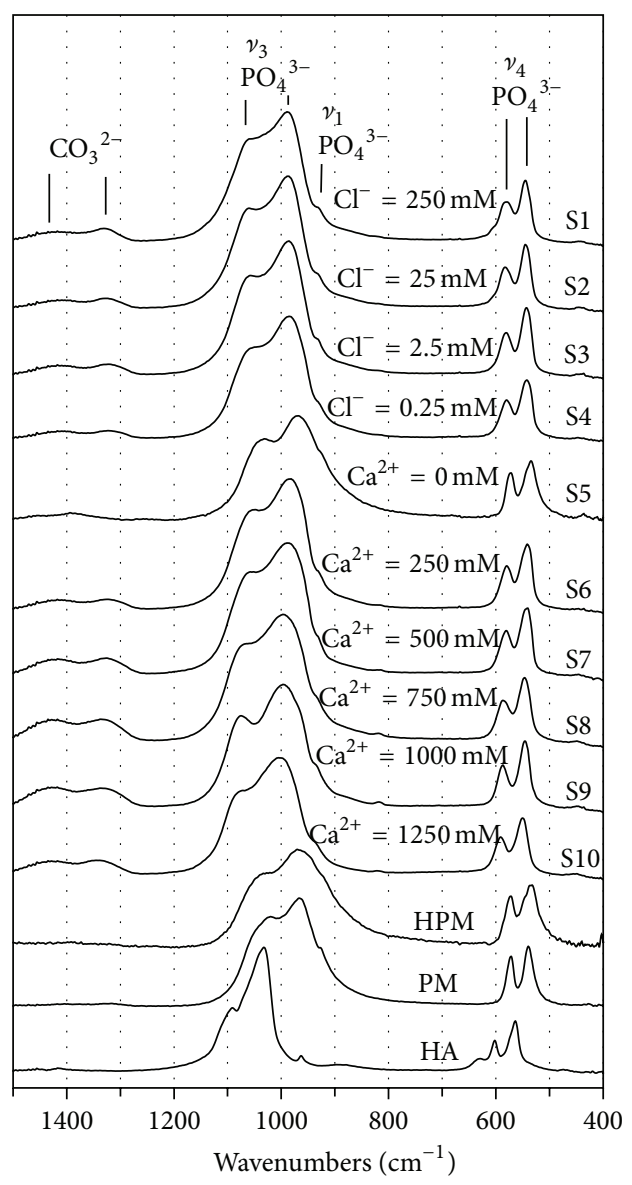

FIGURE 7: Synthetic apatites. FTIR spectra of the synthetic calcium lead apatites S1-S10 together with spectra for hydroxylpyromorphite (HPM), pyromorphite (PM), and hydroxylapatite (HA).

apatite. Phosphate vibrations accounted for the peaks at 950 $1100 \mathrm{~cm}^{-1}, 920 \mathrm{~cm}^{-1}, 590 \mathrm{~cm}^{-1}$, and $540 \mathrm{~cm}^{-1}$. Carbonate vibrations accounted for the low intensity peaks at 1250 $1500 \mathrm{~cm}^{-1}$. The carbonate ions must have been incorporated on the surface of the lead apatite crystals when they were exposed to the atmosphere during the washing, centrifuging, and drying processes. The carbonate vibrations were not due to the presence of cerussite or hydrocerussite as these minerals were absent in the XRD patterns nor were they due to the incorporation of carbonate in the bulk crystal structure as the lead apatite minerals were synthesised under nitrogen gas.

The FTIR spectra from S1, S2, S3, S4, and S6 were similar to each other indicating that the positions of the phosphate peaks are unaffected by the $\mathrm{Cl}: \mathrm{OH}$ ratio in the lead apatite structure. In contrast, the spectra for S5, S6, S7, S8, S9, and $\mathrm{S} 10$ were different from each other. In particular, the $v_{4} \mathrm{PO}_{4}{ }^{3-}$ peaks at $530-590 \mathrm{~cm}^{-1}$ shifted to the to higher wavenumbers as the $\mathrm{Ca}: \mathrm{Pb}$ ratio in the lead apatite structure increased.

The small peaks at $870-880 \mathrm{~cm}^{-1}$ observed on lead pipes P9, P10, P12, and P14 (Figure 4) were absent and instead the samples containing calcium, S6-S10, exhibited small peaks at $820 \mathrm{~cm}^{-1}$. 
TABLE 2: Composition of the target minerals determined from elemental analysis.

\begin{tabular}{|c|c|c|c|c|c|c|c|c|c|c|c|}
\hline \multirow{3}{*}{ Min. } & \multirow{3}{*}{ Repeat } & \multicolumn{5}{|c|}{ Composition in moles } & \multirow{3}{*}{$\mathrm{Pb}+\mathrm{Ca}$} & \multirow{3}{*}{ Divalent cation deficiency } & \multirow{3}{*}{$(\mathrm{Pb}+\mathrm{Ca}) / \mathrm{P}$} & \multirow{3}{*}{$\begin{array}{c}\% \mathrm{Ca} \\
{[\mathrm{Ca} /(\mathrm{Ca}+} \\
\mathrm{Pb})] \times 100\end{array}$} & \multirow{3}{*}{$\mathrm{Pb} / \mathrm{Ca}$} \\
\hline & & \multicolumn{3}{|c|}{ \pm 0.1} & \multicolumn{2}{|c|}{ \pm 0.01} & & & & & \\
\hline & & $\mathrm{Pb}^{2+}$ & $\mathrm{Ca}^{2+}$ & $\mathrm{PO}_{4}{ }^{3-}$ & $\mathrm{Cl}^{-}$ & $\left(\mathrm{OH}^{-}\right)$ & & & & & \\
\hline \multirow{4}{*}{$\mathrm{T} 1$} & A & 3.5 & 1.2 & 3.0 & 0.03 & 0.97 & 4.7 & 0.3 & 1.6 & 26 & 2.9 \\
\hline & $\mathrm{B}$ & 3.4 & 1.4 & 3.0 & 0.00 & 1.00 & 4.8 & 0.2 & 1.6 & 29 & 2.4 \\
\hline & $\mathrm{C}$ & 3.4 & 1.3 & 3.0 & 0.06 & 0.94 & 4.7 & 0.3 & 1.6 & 28 & 2.6 \\
\hline & Av & 3.4 & 1.3 & 3.0 & 0.03 & 0.97 & 4.7 & 0.3 & 1.6 & 28 & 2.6 \\
\hline \multirow{4}{*}{$\mathrm{T} 2$} & A & 3.6 & 1.1 & 3.0 & 0.03 & 0.97 & 4.7 & 0.3 & 1.6 & 23 & 3.3 \\
\hline & B & 3.4 & 1.4 & 3.0 & 0.03 & 0.97 & 4.8 & 0.2 & 1.6 & 29 & 2.4 \\
\hline & C & 3.8 & 1.0 & 3.0 & 0.16 & 0.84 & 4.8 & 0.2 & 1.6 & 20 & 3.8 \\
\hline & Av & 3.6 & 1.2 & 3.0 & 0.07 & 0.93 & 4.8 & 0.2 & 1.6 & 25 & 3.2 \\
\hline \multirow{4}{*}{ T3 } & A & 3.6 & 1.2 & 3.0 & 0.25 & 0.75 & 4.8 & 0.2 & 1.6 & 25 & 3.0 \\
\hline & B & 3.4 & 1.3 & 3.0 & 0.27 & 0.73 & 4.7 & 0.3 & 1.6 & 28 & 2.6 \\
\hline & $\mathrm{C}$ & 3.8 & 1.0 & 3.0 & 0.29 & 0.71 & 4.8 & 0.2 & 1.6 & 28 & 3.8 \\
\hline & Av & 3.6 & 1.2 & 3.0 & 0.27 & 0.73 & 4.8 & 0.2 & 1.6 & 25 & 3.1 \\
\hline
\end{tabular}

TEM images of the synthetic samples S1-S10 (Figure 8) showed particles ranging in size from 10 to $200 \mathrm{~nm}$. Most of the samples comprised well faceted rod-shaped crystals of length $50-200 \mathrm{~nm}$ and width $10-20 \mathrm{~nm}$. However, samples S8 and S10 comprised flakes that were aggregated together. Although there were changes in crystal size and shape it was not possible to correlate this with changes in chloride concentration or calcium concentration in the reaction mixture. Hydroxylapatite typically forms rods that are elongated along the $c$ axis [49] and the same axis of elongation has been reported for pyromorphite crystals [18]. Rod-shaped crystals of lead apatite have also been observed in new lead pipes exposed to phosphate-dosed tap water [14].

3.3. The Target Minerals. The information from Figures 3 and 6 was used to identify the reaction conditions needed to make the target minerals. Powder XRD patterns, unit cell graph, FTIR spectra, and TEM images of the three target minerals are shown in Figures 9(a)-9(d).

Table 2 shows the elemental analysis of the three target minerals, each synthesised in triplicate. The mole ratio of $\mathrm{Pb}^{2+}: \mathrm{Ca}^{2+}: \mathrm{PO}_{4}{ }^{3-}: \mathrm{Cl}^{-}$in each mineral was determined from percentage weight data (not shown). The ratio was normalised by setting the $\mathrm{PO}_{4}{ }^{3-}$ value to 3.0 , this being the number of $\mathrm{PO}_{4}{ }^{3-}$ groups expected in each formula unit. The mole ratio of $\mathrm{OH}^{-}$ions was determined by subtracting the number of moles of $\mathrm{Cl}^{-}$ions from 1.00. Average values were then determined.

The formulae of the three target minerals, as determined from the average mole ratios in Table 2, were

$$
\begin{array}{ll}
\mathrm{Pb}_{3.4} \mathrm{Ca}_{1.3}\left(\mathrm{PO}_{4}\right)_{3} \mathrm{Cl}_{0.03} \mathrm{OH}_{0.97} & \mathrm{~T} 1 \\
\mathrm{~Pb}_{3.6} \mathrm{Ca}_{1.2}\left(\mathrm{PO}_{4}\right)_{3} \mathrm{Cl}_{0.07} \mathrm{OH}_{0.93} & \mathrm{~T} 2 \\
\mathrm{~Pb}_{3.6} \mathrm{Ca}_{1.2}\left(\mathrm{PO}_{4}\right)_{3} \mathrm{Cl}_{0.27} \mathrm{OH}_{0.73} & \mathrm{~T} 3
\end{array}
$$
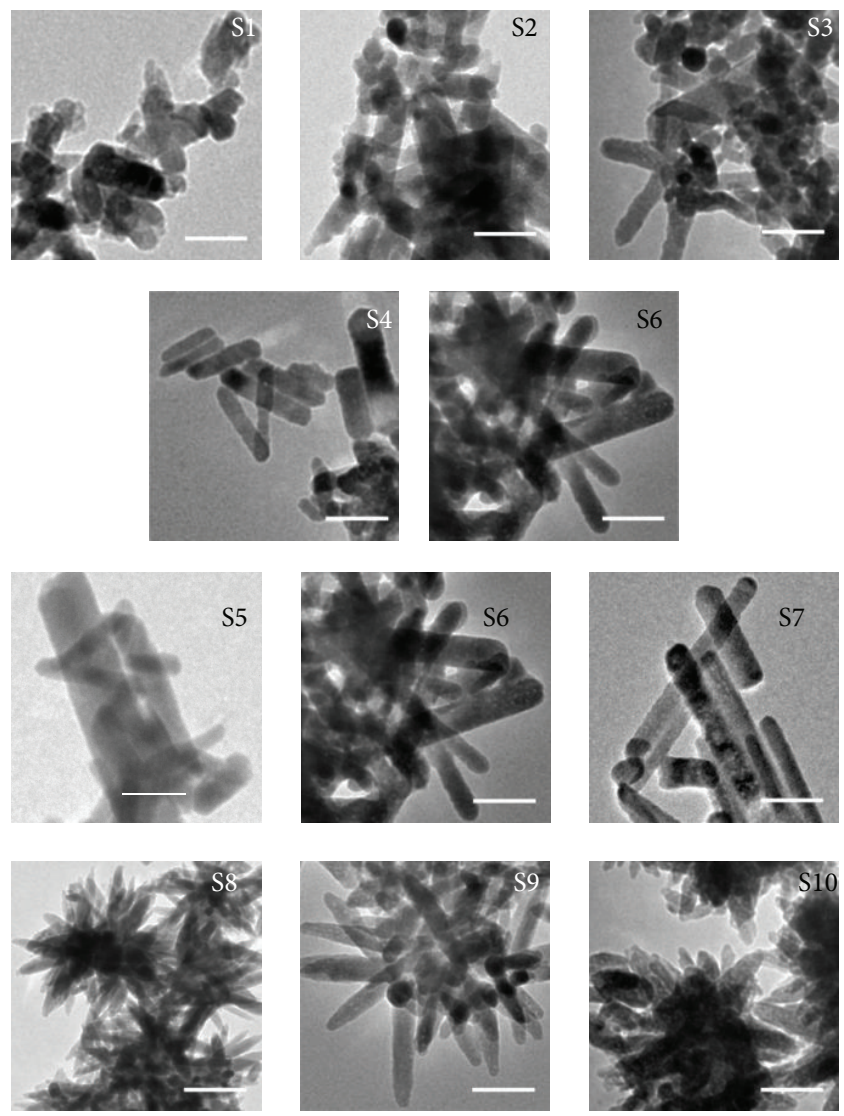

FIGURE 8: TEM images showing the morphology and size of synthetic lead apatites. The effect of increasing the chloride is shown in S1-S4, S6 and the effect of increasing the calcium concentration is shown in S5-S10. Bar markers $=50 \mathrm{~nm}$.

The formulae show that between one and two lead ions are replaced by calcium. This was consistent with the results from 


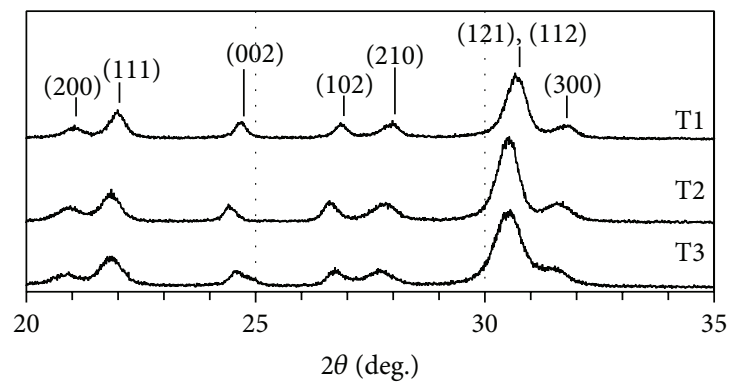

(a)

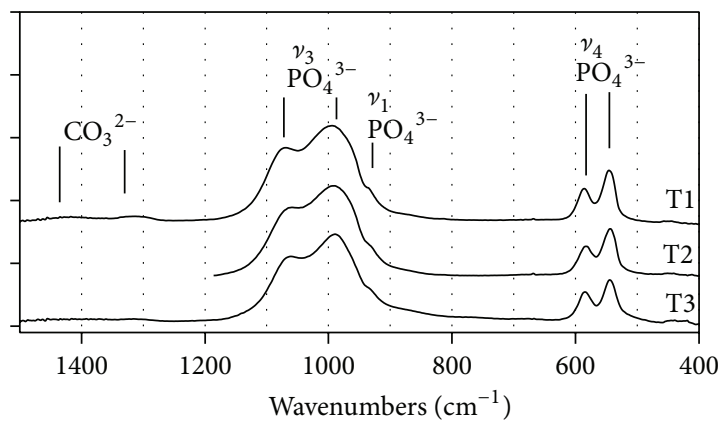

(c)

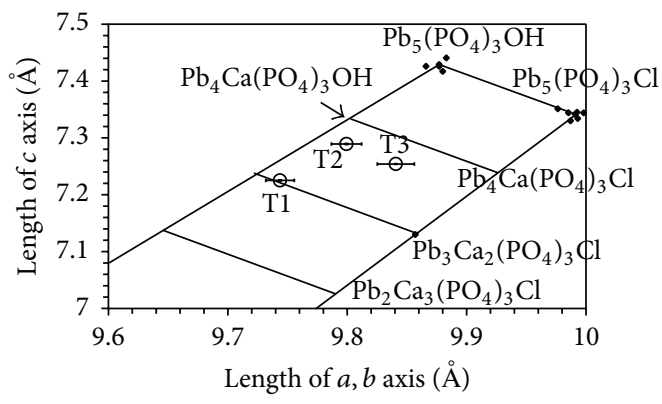

(b)
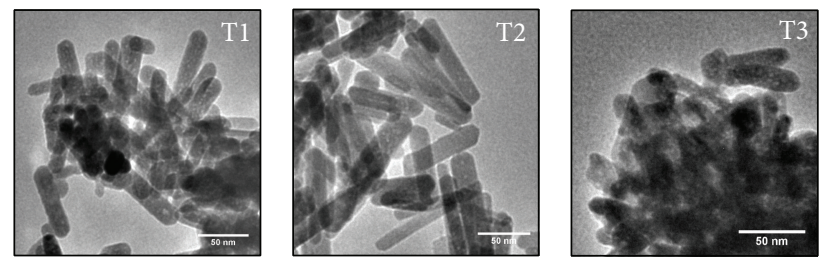

(d)

FIGURE 9: Characterisation of the target minerals, (a) XRD, (b) unit cell graph, (c) FTIR, and (d) TEM (bar markers $=50 \mathrm{~nm}$ ).

TABle 3: Possible formulae of target mineral T1 together with general formulae. Divalent cation vacancies are denoted by the symbol $\square$. Formulae containing carbonate are more complex and are not shown.

\begin{tabular}{lc}
\hline Possible formulae of the charge balanced target mineral T1 & General formula \\
\hline $\mathrm{Pb}_{3.4} \mathrm{Ca}_{1.3} \square_{0.3}\left(\mathrm{PO}_{4}\right)_{2.4}\left(\mathrm{HPO}_{4}\right)_{0.6} \mathrm{OH}_{0.03} \mathrm{Cl}_{0.95}$ & $\mathrm{~Pb}_{5-y-x / 2} \mathrm{Ca}_{y} \square_{x / 2}\left(\mathrm{PO}_{4}\right)_{3-x}\left(\mathrm{HPO}_{4}\right)_{x} \mathrm{OH}_{w} \mathrm{Cl}_{1-w}$ \\
$\mathrm{~Pb}_{3.4} \mathrm{Ca}_{1.3} \mathrm{Na}_{0.3}\left(\mathrm{PO}_{4}\right)_{2.7}\left(\mathrm{HPO}_{4}\right)_{0.3} \mathrm{OH}_{0.03} \mathrm{Cl}_{0.95}$ & $\mathrm{~Pb}_{5-y-x} \mathrm{Ca}_{y} \mathrm{Na}_{x}\left(\mathrm{PO}_{4}\right)_{3-x}\left(\mathrm{HPO}_{4}\right)_{x} \mathrm{OH}_{w} \mathrm{Cl}_{1-w}$ \\
$\mathrm{~Pb}_{3.4} \mathrm{Ca}_{1.3} \square_{0.6}\left(\mathrm{PO}_{4}\right)_{3}\left(\mathrm{H}_{2} \mathrm{O}\right)_{0.6} \mathrm{OH}_{0.4}$ & $\mathrm{~Pb}_{5-y-x / 2} \mathrm{Ca}_{y} \square_{x}\left(\mathrm{PO}_{4}\right)_{3}\left(\mathrm{H}_{2} \mathrm{O}\right)_{x} \mathrm{OH}_{1-x}$ \\
$\mathrm{~Pb}_{3.4} \mathrm{Ca}_{1.3} \mathrm{Na}_{0.3}\left(\mathrm{PO}_{4}\right)_{3}\left(\mathrm{H}_{2} \mathrm{O}\right)_{0.3} \mathrm{OH}_{0.7}$ & $\mathrm{~Pb}_{5-y-x} \mathrm{Ca}_{y} \mathrm{Na}_{x}\left(\mathrm{PO}_{4}\right)_{3}\left(\mathrm{H}_{2} \mathrm{O}\right)_{x} \mathrm{OH}_{1-x}$ \\
Any combination of the above formulae & \\
\hline
\end{tabular}

the unit cell diagram (Figure 9(b)). The closest fit was for minerals T2 and T3. Mineral T1 was predicted from the unit cell diagram to have two lead ions replaced by calcium ions but the actual figure was lower at 1.3. The reason for this discrepancy is not yet known. Mineral T3 had the highest amount of chloride ions. The results show that calcium is incorporated into the lead apatite structure when the $\mathrm{Ca}: \mathrm{Pb}$ ratio in the reaction solution is equal to or greater than $500: 1$.

In all three minerals, the total number of lead and calcium ions was less than 5.0, indicating that the minerals were deficient in calcium and/or lead. Apatites that have a total of 5.0 divalent cations are said to be stoichiometric and have $\mathrm{M}^{2+} / \mathrm{P}$ ratio of 1.7. Samples T1, T2, and T3 were therefore slightly nonstoichiometric, with $\mathrm{M}^{2+} / \mathrm{P}$ ratio of 1.6 (Table 2).

The cationic deficiency implied that species other than $\mathrm{Pb}^{2+}, \mathrm{Ca}^{2+}, \mathrm{PO}_{4}{ }^{3-}, \mathrm{Cl}^{-}$, and $\mathrm{OH}^{-}$were present in the target minerals. In calcium deficient hydroxylapatite, it is thought that some of the $\mathrm{Ca}^{2+}$ ions are missing or replaced with $\mathrm{Na}^{+}$ions. The loss of positive charge is then balanced by the substitution of $\mathrm{PO}_{4}{ }^{3-}$ ions with $\mathrm{HPO}_{4}{ }^{2-}$ or $\mathrm{CO}_{3}{ }^{2-}$ ions or by the substitution of $\mathrm{OH}^{-}$ions with $\mathrm{H}_{2} \mathrm{O}$ molecules. Lead apatites are likely to show similar changes and therefore $\mathrm{Na}^{+}$, $\mathrm{HPO}_{4}{ }^{2-}, \mathrm{CO}_{3}{ }^{2-}$, and $\mathrm{H}_{2} \mathrm{O}$ may all be present as minor components in the target minerals. Their actual formulae might be rather complex as has been proposed for hydroxylapatite [51]. Possible formulae for mineral T1 are shown in Table 3.

Taken together, all the data for the target minerals show that synthetic copies of the lead apatites found on lead water pipes can be made. We hypothesise that the synthetic calcium lead apatites produced in this study (target minerals T1-T3) are similar to apatites found on lead water pipes and that these synthetic apatites can be used in solubility studies to determine their solubility products (Ksp values).

\section{Conclusions}

This study shows that lead water pipes from the county of Yorkshire in Northern England, fed with phosphate-dosed tap water, contain a range of apatite minerals of slightly different chemical formulae, in which both calcium and lead are present. Hydroxylpyromorphite which is the mineral used in solubility studies was not observed. The presence 
of calcium lead apatites instead of hydroxylpyromorphite implies that current solubility models do not give an accurate prediction of lead levels in tap water from Yorkshire.

Analysis of the lead apatites from the walls of the lead pipes showed that for every five lead ions in the general formula $\mathrm{Pb}_{5}\left(\mathrm{PO}_{4}\right)_{3} \mathrm{X}$ between one and two ions were replaced with calcium. There were also differences in the amounts of hydroxide and chloride ions $(\mathrm{X}=\mathrm{OH}$ and/or $\mathrm{Cl}$ ) with most of the calcium lead apatites being richer in hydroxide ions. Phosphohedyphane, in which all the monovalent anions are chloride ions, was not observed although the hydroxyl form of phosphohedyphane $\mathrm{Pb}_{3} \mathrm{Ca}_{2}\left(\mathrm{PO}_{4}\right)_{3} \mathrm{OH}$ may have been present. There was evidence for the substitution of $\mathrm{PO}_{4}{ }^{3-}$ by either $\mathrm{CO}_{3}{ }^{2-}$ or $\mathrm{HPO}_{4}{ }^{2-}$ ions.

Synthetic calcium lead apatites that had similar unit cell dimensions to those found on lead water pipes were successfully made having the formulae $\mathrm{Pb}_{3.4} \mathrm{Ca}_{1.3}\left(\mathrm{PO}_{4}\right)_{3}$ $\mathrm{Cl}_{0.03} \mathrm{OH}_{0.97}, \mathrm{~Pb}_{3.6} \mathrm{Ca}_{1.2}\left(\mathrm{PO}_{4}\right)_{3} \mathrm{Cl}_{0.07} \mathrm{OH}_{0.93}$, and $\mathrm{Pb}_{3.6} \mathrm{Ca}_{1.2}$ $\left(\mathrm{PO}_{4}\right)_{3} \mathrm{Cl}_{0.27} \mathrm{OH}_{0.73}$. In other words, $20-29 \%$ of the lead ions were replaced with calcium (Table 2). These synthetic calcium lead apatites were slightly nonstoichiometric having $\mathrm{M}^{2+} / \mathrm{P}$ ratio of 1.6 as opposed to the stoichiometric value of 1.7. This nonstoichiometry can be explained by the presence of small amounts of $\mathrm{Na}^{+}, \mathrm{HPO}_{4}{ }^{2-}, \mathrm{CO}_{3}{ }^{2-}$, and $\mathrm{H}_{2} \mathrm{O}$ species or by cation vacancies. The synthetic calcium lead apatite crystals appeared as nanosized rods and flakes and were less crystalline than synthetic lead apatites.

\section{Future Work}

Future work will focus on the solubility products and modelling of the solution chemistry using the ion speciation software PHREEQC [52]. These models will be used to optimise phosphate dosing and to shed light on the occurrence of "lead hot spots," where the concentration of lead in tap water is $>10 \mu \mathrm{g} / \mathrm{L}$, which is the current European Union limit for lead. We will also investigate whether there is a correlation between the predicted formulae of the lead pipe apatites and the composition and origin of the tap water flowing through the pipes. Table 3 suggests that $\mathrm{HPO}_{4}{ }^{2-}$ ions are $\mathrm{H}_{2} \mathrm{O}$ molecules which may be present within the calcium lead apatites and we will use spectroscopic techniques to see whether this is true. The distribution of $\mathrm{Ca}$ and $\mathrm{Pb}$ within the apatite structure has important implications for the minerals stability and solubility and we are currently investigating this using atomistic simulations.

\section{Conflict of Interests}

The authors declare that there is no conflict of interests regarding the publication of this paper.

\section{Acknowledgments}

This work was undertaken as part of a Knowledge Transfer Partnership between the University of Huddersfield and Yorkshire Water. The work was funded by Yorkshire Water and a Knowledge Transfer Partnership grant from the UK
Technology Strategy Board. Yorkshire Water is located in the North of England and manages the collection, treatment, and distribution of 1.3 billion litres of drinking water to 5 million people.

\section{References}

[1] L. Stokes, N. C. Onwuche, P. Thomas, and J. O. Davies-Cole, "Blood lead levels in residents of homes with elevated lead in tap water-district of Columbia," Morbidity and Mortality Weekly Report (MMWR), vol. 53, no. 12, pp. 268-270, 2004.

[2] J. P. Ferrie, K. Rolf, and W. Troesken, "Cognitive disparities, lead plumbing, and water chemistry: prior exposure to water-borne lead and intelligence test scores among World War Two U.S. Army enlistees," Economics and Human Biology, vol. 10, no. 1, pp. 98-111, 2012.

[3] D. A. Gidlow, "Lead toxicity," Occupational Medicine, vol. 54, no. 2, pp. 76-81, 2004.

[4] H. Abadin, A. Ashizawa, and Y. W. Stevens, Toxicological Profile for Lead, US Department of Health and Human Services, Agency for Toxic Substances and Disease Registry (ATSDR), Atlanta, Ga, USA, 2007.

[5] H. W. Mielke and S. Zahran, "The urban rise and fall of air lead $(\mathrm{Pb})$ and the latent surge and retreat of societal violence," Environment International, vol. 43, no. 1, pp. 48-55, 2012.

[6] R. Levin, M. J. Brown, M. E. Kashtock et al., "Lead exposures in U.S. children, 2008: implications for prevention," Environmental Health Perspectives, vol. 116, no. 10, pp. 1285-1293, 2008.

[7] G. C. M. Watt, A. Britton, W. Harper Gilmour et al., "Is lead in tap water still a public health problem? An observational study in Glasgow," British Medical Journal, vol. 313, no. 7063, pp. 979981, 1996.

[8] P. T. Cardew, "Simulation of lead compliance data," Water Research, vol. 34, no. 8, pp. 2241-2252, 2000.

[9] P. T. Cardew, "Measuring the benefit of orthophosphate treatment on lead in drinking water," Journal of Water and Health, vol. 7, no. 1, pp. 123-131, 2009.

[10] A. Robeznieks, “The long shadow of Flint's lead crisis," Modern Healthcare, vol. 45, no. 41, p. 9, 2015.

[11] J. H. Colling, P. A. E. Whincup, and C. R. Hayes, “The measurement of plumbosolvency propensity to guide the control of lead in tapwaters," Water and Environment Journal, vol. 1, no. 3, pp. 263-269, 1987.

[12] J. H. Colling, B. T. Croll, P. A. E. Whincup, and C. Harward, "Plumbosolvency effects and control in hard waters," Journal of the Institution of Water and Environmental Management, vol. 6, no. 3, pp. 259-268, 1992.

[13] E. J. Kim and J. E. Herrera, "Characteristics of lead corrosion scales formed during drinking water distribution and their potential influence on the release of lead and other contaminants," Environmental Science \& Technology, vol. 44, no. 16, pp. 6054-6061, 2010.

[14] M. N. Nadagouda, M. Sehock, D. H. Metz, M. K. Desantis, D. Lytle, and M. Welch, "Effect of phosphate inhibitors on the formation of lead phosphate/carbonate nanorods, microrods, and dendritic structures," Crystal Growth \& Design, vol. 9, no. 4, pp. 1798-1805, 2009.

[15] C. M. Davidson, N. J. Peters, A. Britton, L. Brady, P. H. E. Gardiner, and B. D. Lewis, "Surface analysis and depth profiling of corrosion products formed in lead pipes used to supply low 
alkalinity drinking water," Water Science and Technology, vol. 49, no. 2, pp. 49-54, 2004.

[16] P. Leroy, "Lead in drinking water-origins; solubility; Treatment," Journal of Water Supply: Research and TechnologyAqua, vol. 42, no. 4, pp. 233-238, 1993.

[17] I. Sheiham and P. J. Jackson, "The scientific basis for control of lead in drinking water by water treatment," Journal of the Institution of Water Engineers and Scientists, vol. 35, no. 6, pp. 491-515, 1981.

[18] J. D. Hopwood, R. J. Davey, M. O. Jones, R. G. Pritchard, P. T. Cardew, and A. Booth, "Development of chloropyromorphite coatings for lead water pipes," Journal of Materials Chemistry, vol. 12, no. 6, pp. 1717-1723, 2002.

[19] J. C. Elliott, R. M. Wilson, and S. E. P. Dowker, "Apatite structures," Advances in X-Ray Analysis, vol. 45, pp. 172-181, 2002.

[20] Lead Control Strategies, AWWA Research Foundation, Denver, Colo, USA, 1990.

[21] S. M. Grimes, S. R. Johnston, and D. N. Batchelder, "Lead carbonate-phosphate system: solid-dilute solution exchange reactions in aqueous systems," Analyst, vol. 120, no. 11, pp. 27412746, 1995.

[22] N. J. Peters, C. M. Davidson, A. Britton, and S. J. Robertson, "The nature of corrosion products in lead pipes used to supply drinking water to the City of Glasgow, Scotland, UK,' Fresenius' Journal of Analytical Chemistry, vol. 363, no. 5-6, pp. 562-565, 1999.

[23] A. R. Kampf, I. M. Steele, and R. A. Jenkins, "Phosphohedyphane, $\mathrm{Ca}_{2} \mathrm{~Pb}_{3}\left(\mathrm{PO}_{4}\right)_{3} \mathrm{Cl}$, the phosphate analog of hedyphane: description and crystal structure," American Mineralogist, vol. 91, no. 11-12, pp. 1909-1917, 2006.

[24] J. M. Hughes, M. Cameron, and K. D. Crowley, "Structural variations in natural F, $\mathrm{OH}$, and $\mathrm{Cl}$ apatites," American Mineralogist, vol. 74, no. 7-8, pp. 870-876, 1989.

[25] L. M. Rodríguez-Lorenzo, J. N. Hart, and K. A. Gross, "Structural and chemical analysis of well-crystallized hydroxyfluorapatites," Journal of Physical Chemistry B, vol. 107, no. 33, pp. 83168320, 2003.

[26] P. E. Mackie, J. C. Elliot, and R. A. Young, "Monoclinic structure of synthetic $\mathrm{Ca}_{5}\left(\mathrm{PO}_{4}\right)_{3} \mathrm{Cl}$, chlorapatite," Acta Crystallographica Section B-Structural Crystallography and Crystal Chemistry, vol. 28, no. 6, pp. 1840-1848, 1972.

[27] S. Brückner, G. Lusvardi, L. Menabue, and M. Saladini, "Crystal structure of lead hydroxyapatite from powder X-ray diffraction data," Inorganica Chimica Acta, vol. 236, no. 1-2, pp. 209-212, 1995.

[28] J. Y. Kim, B. A. Hunter, R. R. Fenton, and B. J. Kennedy, "Neutron powder diffraction study of lead hydroxyapatite," Australian Journal of Chemistry, vol. 50, no. 11, pp. 1061-1065, 1997.

[29] Y. Dai and J. M. Hughes, "Crystal-structurre refinements of vanadinite and pyromorphite," Canadian Mineralogist, vol. 27, pp. 189-192, 1989.

[30] H. Hashimoto and T. Matsumoto, "Structure refinements of two natural pyromorphites, $\mathrm{Pb}_{5}\left(\mathrm{PO}_{4}\right)_{3} \mathrm{Cl}$, and crystal chemistry of chlorapatite group, $\mathrm{M}_{5}\left(\mathrm{PO}_{4}\right)_{3} \mathrm{Cl}$," Zeitschrift fur Kristallographie, vol. 213, no. 11, pp. 585-590, 1998.

[31] A. Akao, H. Aoki, Y. Innami, S. Minamikata, T. Yamada, and A. Akao, "Flux growth and crystal structure of pyromorphite," Reports of the Institute for Medical and Dental Engineering, Tokyo Medical and Dental University, vol. 23, pp. 25-29, 1989.
[32] W. E. Baker, "An x-ray diffraction study of synthetic members of the pyromorphite series," American Mineralogist, vol. 51, pp. 1712-1721, 1966.

[33] M. S. Sader, K. Lewis, G. A. Soares, and R. Z. LeGeros, "Simultaneous incorporation of magnesium and carbonate in apatite: effect on physico-chemical properties," Materials Research, vol. 16, no. 4, pp. 779-784, 2013.

[34] H. B. Pan and B. W. Darvell, "Effect of carbonate on hydroxyapatite solubility," Crystal Growth \& Design, vol. 10, no. 2, pp. 845-850, 2010.

[35] V. Laperche, S. J. Traina, P. Gaddam, and T. J. Logan, "Chemical and mineralogical characterizations of $\mathrm{Pb}$ in a contaminated soil: reactions with synthetic apatite," Environmental Science \& Technology, vol. 30, no. 11, pp. 3321-3326, 1996.

[36] K. G. Scheckel and J. A. Ryan, "Influence of Aging and pH on Dissolution kinetics and stability of pyromorphite," Geology and Environmental Sciences, 2002.

[37] J. Cotter-Howells, "Lead phosphate formation in soils," Environmental Pollution, vol. 93, no. 1, pp. 9-16, 1996.

[38] K. G. Scheckel, A. G. B. Williams, G. Mc Dermott, D. Gratson, D. Neptune, and J. A. Ryan, "Lead speciation and bioavailability in apatite-amended sediments," Applied and Environmental Soil Science, vol. 2011, Article ID 689568, 8 pages, 2011.

[39] M. J. Quina, J. C. M. Bordado, and R. M. Quinta-Ferreira, "The influence of $\mathrm{pH}$ on the leaching behaviour of inorganic components from municipal solid waste APC residues," Waste Management, vol. 29, no. 9, pp. 2483-2493, 2009.

[40] Y. Nomura, K. Fujiwara, M. Takada, S. Nakai, and M. Hosomi, "Lead immobilization in mechanochemical fly ash recycling," Journal of Material Cycles and Waste Management, vol. 10, no. 1, pp. 14-18, 2008.

[41] J. Jianguo, W. Jun, X. Xin, W. Wei, D. Zhou, and Z. Yan, "Heavy metal stabilization in municipal solid waste incineration flyash using heavy metal chelating agents," Journal of Hazardous Materials, vol. 113, no. 1-3, pp. 141-146, 2004.

[42] M. P. Sternlieb, J. D. Pasteris, B. R. Williams, K. A. Krol, and C. H. Yoder, "The structure and solubility of carbonated hydroxyl and chloro lead apatites," Polyhedron, vol. 29, no. 11, pp. 2364$2372,2010$.

[43] L. Jean and B. Bernard, Checkcell-A Software Performing Automatic Cell/Space Group Determination, Collaborative Computational Project, Laboratoire des Matériaux et du Génie Physique de l'Ecole Supérieure de Physique de Grenoble (INPG), Grenoble, France, 2000.

[44] D. A. Lytle, M. R. Schock, and K. Scheckel, "The inhibition of $\mathrm{Pb}(\mathrm{IV})$ oxide formation in chlorinated water by orthophosphate," Environmental Science \& Technology, vol. 43, no. 17, pp. 6624-6631, 2009.

[45] V. Laperche and S. J. Traina, "Immobilization of Pb by hydroxylapatite," in Absorption of Metals by Geomedia, E. A. Jenne, Ed., Academic Press, New York, NY, USA, 1998.

[46] R. L. Frost and S. J. Palmer, "A Raman spectroscopic study of the phosphate mineral pyromorphite $\mathrm{Pb}_{5}\left(\mathrm{PO}_{4}\right)_{3} \mathrm{Cl}$," Polyhedron, vol. 26, no. 15, pp. 4533-4541, 2007.

[47] T. Bajda, W. Mozgawa, M. Manecki, and J. Flis, "Vibrational spectroscopic study of mimetite-pyromorphite solid solutions," Polyhedron, vol. 30, no. 15, pp. 2479-2485, 2011.

[48] I. L. Botto, V. L. Barone, J. L. Castiglioni, and I. B. Schalamuk, "Characterization of a natural substituted pyromorphite," Journal of Materials Science, vol. 32, no. 24, pp. 6549-6553, 1997. 
[49] D. Walsh, J. L. Kingston, B. R. Heywood, and S. Mann, "Influence of monosaccharides and related molecules on the morphology of hydroxyapatite," Journal of Crystal Growth, vol. 133, no. 1-2, pp. 1-12, 1993.

[50] M. Öner and Ö. Doğan, "Inhibitory effect of polyelectrolytes on crystallization kinetics of hydroxyapatite," Progress in Crystal Growth and Characterization of Materials, vol. 50, no. 1-3, pp. 39-51, 2005.

[51] O. Frank-Kamenetskaya, A. Kol'tsov, M. Kuz'mina, M. Zorina, and L. Poritskaya, "Ion substitutions and non-stoichiometry of carbonated apatite- $(\mathrm{CaOH})$ synthesised by precipitation and hydrothermal methods," Journal of Molecular Structure, vol. 992, no. 1-3, pp. 9-18, 2011.

[52] D. L. Parkhurst and C. A. J. Appelo, “User's guide to PHREEQC (version 2.0), a computer program for speciation, batchreaction, one-dimensional transport, and inverse geochemical calculations," Water-Resources Investigations Report 99-4259, US Geological Survey, Reston, Va, USA, 1999. 

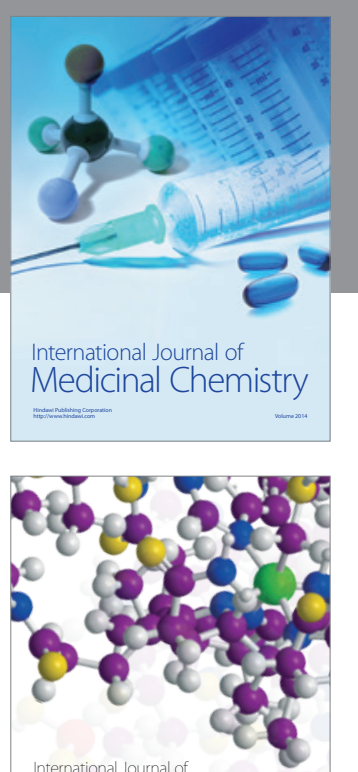

Carbohydrate Chemistry

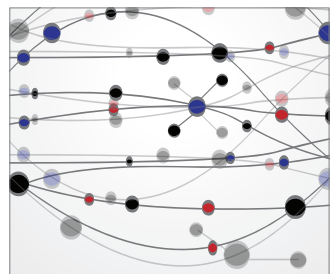

The Scientific World Journal
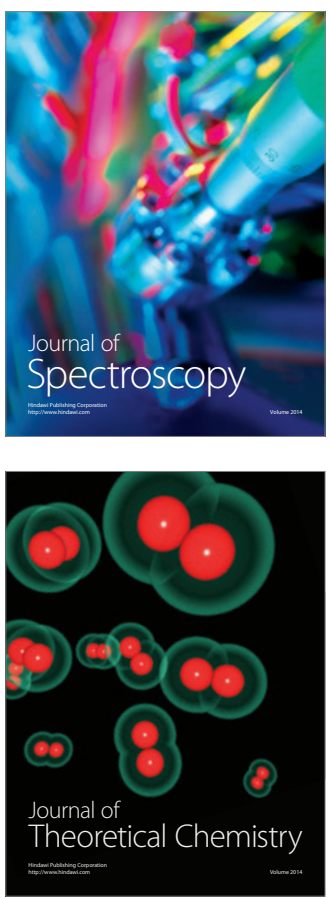
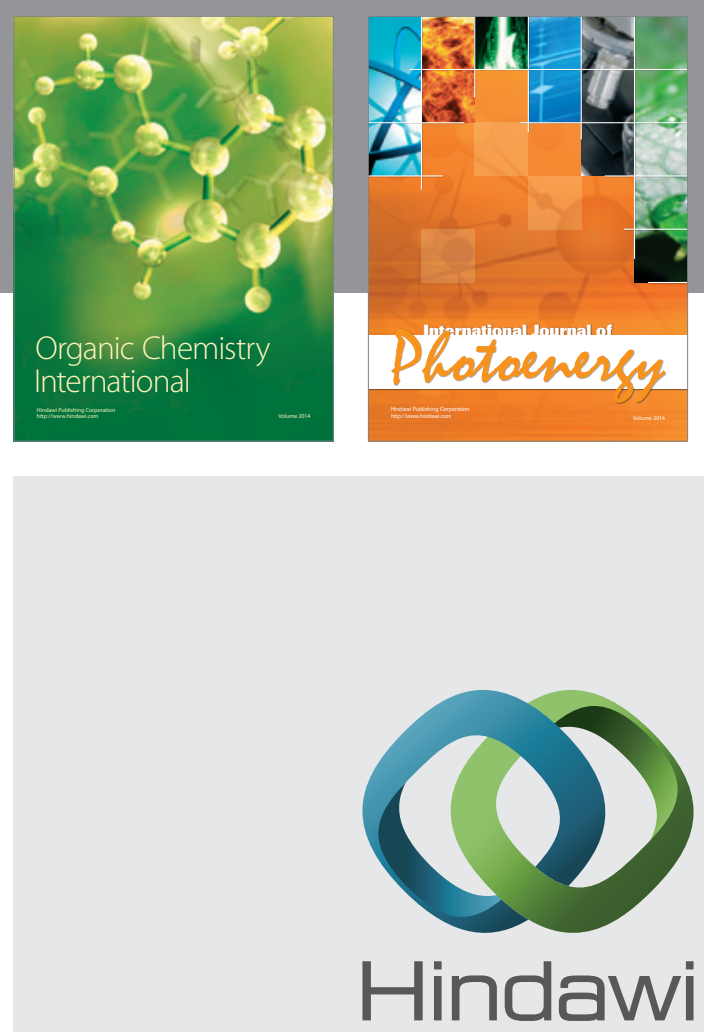

Submit your manuscripts at

http://www.hindawi.com

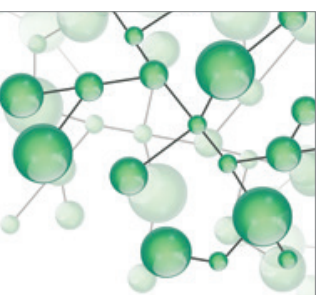

International Journal of

Inorganic Chemistry

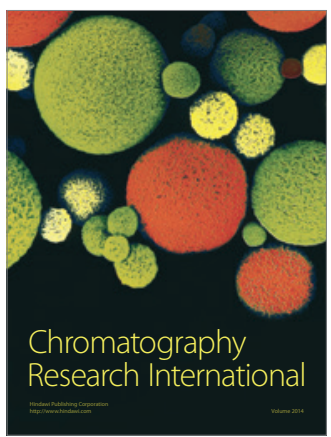

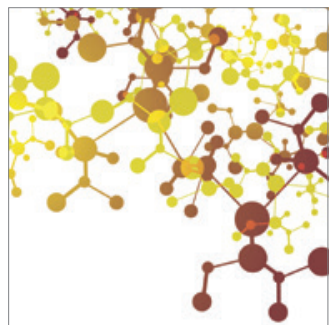

Applied Chemistry
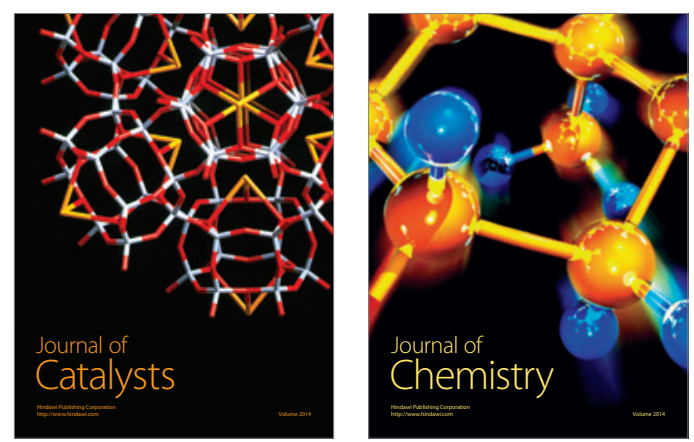
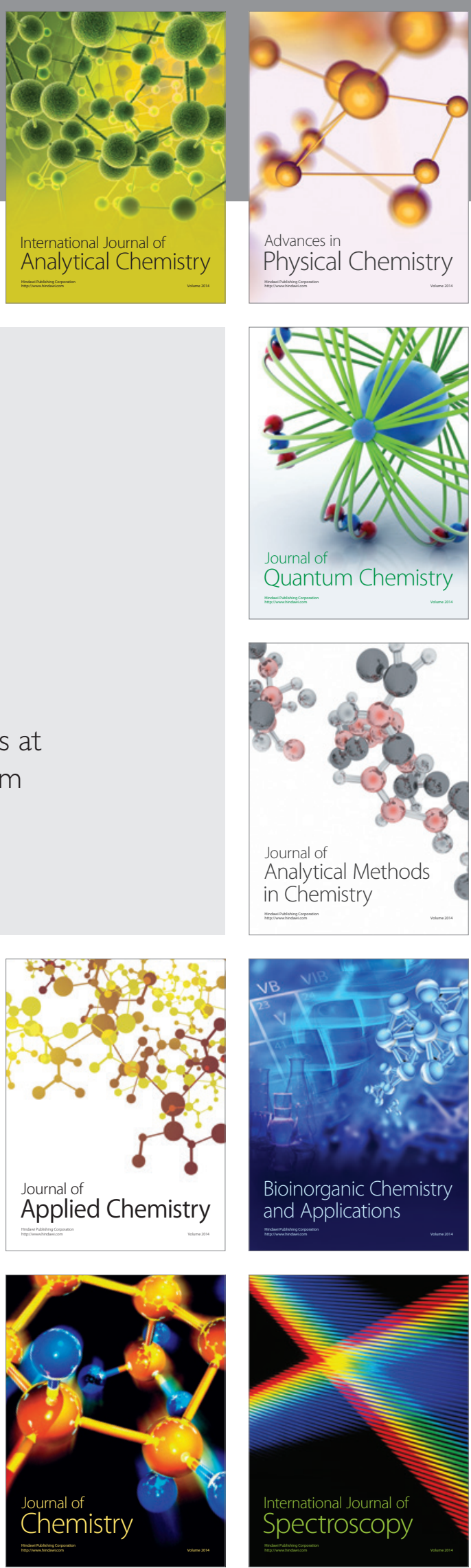